\title{
Restoration of blanket peatlands
}

\author{
Lauren E. Parry ${ }^{1}$, Joseph Holden ${ }^{1}$ and Pippa J. Chapman ${ }^{1}$ \\ ${ }^{1}$ water@leeds, School of Geography, University of Leeds, Leeds, LS2 9JT, UK. \\ Corresponding author: Lauren E Parry; L.E.Parry@leeds.ac.uk; +44 (0) 1133430702
}

\begin{abstract}
:
There is concern that ecosystem services provided by blanket peatlands have come under threat due to increasing degradation. Blanket peatlands are subject to a wide range of drivers of degradation and are topographically variable. As a result, many degradation forms can develop, including those resulting from eroding artificial drainage, incising gullies and areas of bare peat. Many degraded blanket peatlands have undergone restoration measures since the turn of the century. However, there has been little formal communication of the techniques used and their success. Using practitioner knowledge and a review of the available literature, this paper discusses the methodologies used for restoring sloping blanket peatlands. It then considers current understanding of the impact of restoration on blanket peatland ecosystem services. There is a paucity of research investigating impacts of several common restoration techniques and much more is needed if informed management decisions are to be made and funding is to be appropriately spent. Where data are available we find that restoration is largely beneficial to many ecosystem services, with improvements being observed in water quality and ecology. However, the same restoration technique does not always result in the same outcomes in all locations. The difference in response is predominantly due to the spatial and temporal heterogeneity inherent in all blanket peatlands. Peatland practitioners must take this variability into account when designing restoration strategies and monitoring impact.
\end{abstract}

\section{Keywords:}

Peatland, restoration, ecosystem services, bare peat, artificial drainage, gully 


\section{Causes, consequences and characteristics of blanket peatland degradation}

\subsection{Introduction}

Peatlands are sensitive systems, which require specific climatic conditions and poor drainage to grow, develop and remain stable (Holden, 2005b). Blanket peatlands are characterised by their ability to cover sloping landscapes, where peatlands would otherwise not be able to form (Charman, 2002). Conditions have been favourable for the development of blanket peatlands in many areas of the world throughout the Holocene including parts of Atlantic northwest Europe, western Canada, southern Alaska, Tasmania, the South Island of New Zealand, the southern tip of South America and eastern Russia (Gallego-Sala and Colin Prentice, 2012). Most blanket peatlands are found in temperate, hyperoceanic, coastal regions of the world (Lindsay et al., 1988). In these areas the human population is typically very dense and as a result interaction between humans and blanket peatlands is considerable. For example, in the UK, blanket peatlands are semi-natural environments, initiated by anthropogenic burning and forest clearance in the early Holocene (Smith and Cloutman, 1988). However, changes in human interaction with blanket peatlands in the last 200 years as a result of industrialisation, mechanisation and increased demand for land have led to blanket peatland degradation (Holden et al., 2007b). There is plenty of evidence for blanket peatland degradation, such as eroding and bare peatlands (Evans and Warburton, 2007) and increased heavy metal content as a result of industrial pollution (Rothwell et al., 2007).

Blanket peatlands provide human populations with a wide range of ecosystem services, including water provision, carbon storage, landscapes for leisure activities, pasture for sheep, deer, and other game, biodiversity and river flow regulation. Threats to ecosystem services have resulted in many programmes to restore and prevent degradation of these vulnerable, yet highly valuable, blanket peatlands. Many techniques have been developed to carry out peatland restoration and deal with the logistical difficulties of restoring often remote and sloping land. However, there has been little widely available communication on these practices (Holden et al., 2008b). This article briefly reviews the causes, characteristics and consequences of blanket peatland degradation. It then focuses on how blanket peatlands are currently being restored and evaluates the evidence of success and causes of failure for some of these techniques.

\subsection{Blanket peatland hydrology and ecology}

Peatlands are 'living landforms' (Charman, 2002) which are made up of partially decomposed organic matter, which has accumulated over millennia under mainly waterlogged conditions. In healthy blanket peatlands the living vegetation both protects the peat surface from weathering and erosion and accumulates to become peat. Both hydrology and ecology are closely related and important components of blanket peatland condition and development. Blanket peatlands are predominantly ombrotrophic, meaning they receive the vast majority of their water and nutrients solely from 
precipitation. On blanket peatlands saturation-excess overland flow or very shallow throughflow dominates flow production, resulting in flashy stream hydrographs, while the low hydraulic conductivity of deeper peat holds the remaining water within the peat resulting in very little baseflow provision (Price, 1992; Holden and Burt 2003). Networks of macropores (Holden, 2009) and natural soil pipes can also rapidly transport water through the peat profile (Holden and Burt, 2002). Hydrological conditions, such as stream velocity and water table level, are variable across blanket peatlands as a result of varying topography (Holden et al., 2006). Blanket peatland vegetation tends to be dominated by bryophytes including Sphagnum species, sedges such as Eriophorum species and dwarf shrubs such as Erica and Calluna species. Such species are adapted to waterlogged and nutrient-poor conditions. The vegetation communities are sensitively adapted to small-scale hydrological niches and this variability, together with autogenic processes, results in the zoning of blanket peatland vegetation (Lindsay, 2010). Peatland species each have a differing resistance to decay and sensitivity to change (Clymo, 1987) . As a result, the interaction between hydrology and ecology controls both the development of peatland landforms, such as hummocks and hollows, and peatland sensitivity to change and degradation (Belyea, 1996; Belyea and Clymo, 2001).

\subsection{Drivers of blanket peatland degradation}

Blanket peatlands can be easily destabilised by change in hydrological and ecological conditions and if sustained this leads to physical degradation. Changes in peatland stability can be caused by a number of external and internal pressures on the blanket peatland environment.

\section{External pressures}

Climate Change: Blanket peatland development is strongly determined by climate. Past changes in climate, such as a reduction in precipitation and increase in temperature during the medieval warm period (950-1100 AD), have been shown to cause drying, change in vegetation composition and promotion of erosion in blanket peatlands (Ellis and Tallis, 2001; Tallis, 1997). Climate change will begin to affect increasingly large areas of blanket peatland in the next century (Gallego-Sala and Prentice, 2012; Clark et al, 2010; Gallego-Sala et al, 2012). This may lead to conditions which make blanket peatland degradation more likely.

Atmospheric Pollution: Many blanket peatlands, particularly those in the UK, are located near heavily industrialised cities that have emitted large amounts of heavy metals, sulphur dioxide $\left(\mathrm{SO}_{2}\right)$ and nitrous oxides $\left(\mathrm{NO}_{\mathrm{x}}\right)$ into the atmosphere. As a result of high levels of precipitation, much of this pollution has been deposited on blanket peatland surfaces. Peatland vegetation, particularly Sphagnum mosses, are sensitive to atmospheric pollution (Smart et al., 2010) and as a result atmospheric pollution is linked to the exposure of large areas of bare peat and the initiation of gullies in blanket peat areas, such as in the Peak District of the UK (Phillips et al., 1981). Although the recent decline in 
atmospheric pollution has removed some of the direct impacts, the legacy and degradation caused by atmospheric pollution still remains a challenge to many peatland managers.

\section{Internal pressures}

Peat Extraction: Subsistence hand cutting of peat has provided fuel for blanket peat-rich locations, such as Ireland, for centuries (Cruickshank et al., 1995). The mechanisation of peat cutting in the 1980s fuelled the growth of the horticulture and peat fuel industries and caused a rapid expansion in the areas of peat being cut (Cooper and McCann, 1995). This has placed considerable pressure on blanket peatlands, particularly in parts of Canada and Ireland, causing landscape-scale areas of bare peat, significant disturbance in hydrological functioning, irreversible damage to peatland ecology and reduction of the blanket peat stock (Farrell and Doyle, 2003).

Artificial drainage: Artificial drainage has been carried out on blanket peatland to lower water tables in preparation for peat cutting, in response to increased agricultural demand for livestock grazing and for the management of grouse shooting estates (Holden et al., 2006). It is thought that over 1.5 million hectares of blanket peatland was drained in upland Britain, potentially causing significant changes in the peatland environment (Holden et al., 2004). This includes alteration in river flow regime, erosion, enhanced aquatic carbon release, changes in stream invertebrate communities (Ramchunder et al., 2012) and modification of peat structure and hydrological flow paths (Armstrong et al., 2009; Holden et al., 2006; Holden et al., 2007a).

Grazing: Blanket peatlands are susceptible to damage from low levels of sheep grazing. Grazing can initiate and exacerbate erosion (Ellis and Tallis, 2001) and result in a vegetation change towards more vascular vegetation species (Ward et al., 2007). However, the presence of grazing animals also prevents the colonisation of successional vegetation species such as birch. Indeed, human encouragement of grazing after forest clearance in the early Holocene, in some locations such as the British Isles, probably supported further blanket peat development once it was initiated (Simmons, 2003).

Prescribed burning: Prescribed rotational patch burning of heather is used as an ecological management tool to produce heather stands of different ages, which increase habitat structural diversity that support populations of game birds, such as grouse (Lagapus lagapus L.) (Davies et al., 2008) and to provide fresh bite for grazing stock (Mercer, 2009). It is thought, particularly in the UK, that the intensity, severity and extent of burning have increased in some places in recent decades (Davies et al., 2008; Yallop et al., 2006). This, in turn, will have had adverse effects on blanket peatland condition and development. These can include crusting and exposure of bare peat, initiation of erosion (which impacts stream macro-invertebrate communities (Ramchunder et al., 2013)) 
changes to peat biogeochemistry and potentially the increased release of dissolved organic carbon (DOC) into stream waters (Holden et al., 2012a).

Wildfire: Although unplanned fires do not occur as often as prescribed burning, they can cover very large areas and in some cases are more intense and severe (Davies et al., 2008). Wildfires can result in peat ignition and the exposure of large areas to erosion (Albertson et al., 2010).

Afforestation: During the $20^{\text {th }}$ century many blanket peatlands were commercially forested, particularly in the UK and Ireland (Wellock et al., 2011; Holden et al., 2007). To prepare peatlands for commercial forestry, narrowly spaced artificial drainage ditches are dug and fertiliser is applied to the peatland (Holden et al., 2007b). Commercial forestry is often very dense, which results in severely reduced light levels and increased transpiration and interception rates. These changes can considerably alter peatland conditions in the area within and surrounding an afforested peatland (Holden et al., 2007b).

Infrastructure: Installation of access tracks and buildings for forestry, windfarms and estate management can disturb considerable quantities of peat and alter ecological and hydrological characteristics of a peatland. Often this damage occurs beyond the footprint of the feature alone because infrastructure alters the flow paths for water across a peatland site, the effects of which could range from within a few meters to over fifty metres from the feature itself (e.g. from a windfarm access track constructed across a blanket peat hillslope) (Holden, 2005b).

\subsection{Blanket peat degradation and topographic variability}

Blanket peatlands occur on rolling terrain. A complex group of erosional landforms can form on an individual site (Figure 1) depending on their topographic position within the terrain and on the drivers of degradation. Typically, more gentle gradient hilltops or more extended flat areas can be subject to development of peat pans which are extensive areas of bare peat. Occasionally there will be hagg features which are isolated masses of eroding peat, typically with an exposed bare peat face on the sides and a vegetated top. Such haggs are often orientated in the direction of prevailing wind indicating the role that wind-assisted rain splash has on shaping such landforms (Foulds and Warburton, 2007). These landforms are detached from the main hydrological network and are typically found on exposed summits. For features such as gullies, the sloping terrain of many blanket peatlands leads to variability in their form; on gentle slopes gullies occur in branching, dendritic gully networks whereas on steep slopes gullies are more singular and run parallel (Bower, 1960). Similarly, there is evidence that underground erosional networks known as peat pipes (Jones, 1981; Holden et al., 2012b) are more branching and bifurcating in form on gentle slopes and are singular and parallel 
on steeper slopes, but this may depend on the history of peat development at a site (Holden, 2005a). Drains on steep blanket peat slopes tend to erode at faster rates than those on more gentle slopes (Holden et al., 2007a). Such variability means restoration projects will often need to take a flexible approach to restoration, incorporating a number of techniques and adapting individual strategies to the surrounding topographical conditions and positioning within the landscape (Holden, 2005b).

Typically blanket peatland restoration techniques target both geomorphic (e.g. gullies and peat pans) and more direct human intervention features of degradation (e.g. ditches), which are thought to cause hydrological and ecological instability which negatively impact upon ecosystem services. The features typically targeted in blanket peat restoration include, but are not restricted to:

1. Artificial drainage ditches: steep sided channels cut into the peat surface often in dense herring bone pattern networks.

2. Gullies: incised channels formed by running water.

3. Peat pans and flats: large unvegetated areas of bare peat.

4. Peat haggs: isolated masses of eroding peat, typically with an exposed bare peat face on the sides and a vegetated top. These features are detached from the main hydrological network and are typically found on exposed summits.

5. Peat piping: subsurface hydrological macropore networks within the peat body.

\section{INSERT FIGURE ONE HERE}

\subsection{Blanket peatland degradation and ecosystem services}

Degraded blanket peatlands impact a range of ecosystem services. Here we provide some illustrative examples of impacts of degradation on ecosystem services to highlight this issue, although we note that these examples are by no means exhaustive.

If a site is badly eroded then the peatland is not able to sustain any further grazing and so the ability of the peatland to provide goods associated with grazing is lost. Severe erosion can also destabilise any infrastructure on site such as access tracks, resulting in a loss of livelihoods or access to provisioning services. Many blanket peatlands are in headwater areas supplying water to consumers downstream. Poor water quality can occur in degraded peatlands which impacts downstream fisheries and water supplies. Enhanced dissolved organic carbon (DOC) concentrations associated with degraded blanket peatlands are costly for water companies to treat (Wallage et al., 2006). High sediment loads can rapidly infill reservoirs that are downstream of blanket peatlands (Labadz et al., 1991). The sediment may also be rich in heavy metals deposited since the industrial revolution thereby exacerbating water quality problems (Rothwell et al., 2005). Degraded peatlands may also lose their climate regulation function and instead serve to exacerbate carbon release to the atmosphere (Worrall et al., 2009). There 
is also some evidence to suggest that removal of vegetation cover increases the flashiness of the stream flow response downstream and thereby increases flood risk (Grayson et al., 2010; Holden et al., 2008a). Artificial drainage may also have this effect (Wilson et al., 2011c) but the exact impacts can depend on the topographic configuration of the drainage network (Holden et al., 2004).

Degradation of blanket peat may also destroy the palaeoarchive suitable for environmental research. However, degraded blanket peatlands also provide conditions that are better for providing some cultural ecosystem services. While eroding blanket peatlands provide difficult terrain for walking, some visitors to eroding peatlands enjoy exploring this sort of terrain (Chapman, 1993). Some blanket peat ecosystem services such carbon storage in the soil (Wellock et al., 2011) have been negatively impacted through afforestation for commercial forestry; however, an ecosystem service is also provided by afforestation as a result of the provision of employment and timber goods.

\subsection{Policy, finance and blanket peat restoration}

Since the turn of the century there has been a significant increase in the number of blanket peatland restoration projects. Many blanket peatlands are subject to international and national environmental legislation and it is this protection which has driven the increasing number of peatland restoration projects. For example, in the European Union, the Habitats Directive adopted in 1992 and reforms to the European agricultural subsidy system known as the Common Agricultural Policy (CAP) have led to many restoration projects in the UK and Ireland (Holden et al., 2008; Renou-Wilson et al., 2011). Finances for blanket peatland restoration are provided by a number of different pathways. The EU LIFE programme, an initiative to support environment and nature conservation projects in the EU, has been a major funding source for several large restoration projects including Moors for the Future in the UK (http://www.moorsforthefuture.org.uk) and Active Blanket Bog, in Ireland (http://www.irishbogrestorationproject.ie). CAP reform in 2003 has also provided a significant amount of funding, through payments for environmental provision and in England there are environmental stewardship schemes which formalise such payments. The negative consequences of peatland degradation on ecosystem services have resulted in other financing drivers for restoration projects. For example, a number of private UK water companies are investing in peatland restoration in order to improve water quality at source rather than invest in more energy and chemical intensive treatment plants downstream. Carbon markets are likely to become an increasingly important funding stream too, as a result of the recent inclusion of ditch blocking in peatlands into the Kyoto Protocol (Joosten, 2012). For example, the UK has adopted a pilot 'peatland carbon code' for businesses to pay into corporate social responsibility benefits emerging from peatland restoration (IUCN, 2013). Often restoration is not funded by a single source and most restoration projects are funded as part of a partnership, frequently with a governmental organisation on their board (Holden et al., 2008b). 


\section{Techniques for restoring degraded blanket peatlands}

The first large scale blanket peat restoration projects occurred in the late 1980s and early 1990s. Some of these were in response to large wildfires and often included simple management strategies such as the exclusion of grazing (Anderson et al., 1997) while others targeted particular features of the landscape such as ditches (Armstrong et al., 2009). As funding increased, stakeholder interest in blanket peatland restoration grew and the techniques used began to progress. Now multiple techniques can be applied to most forms of blanket peatland degradation and strategies are tailored to suit individual blanket peatland variability. Increasingly, projects aim to deliver multiple benefits, such as the stabilisation of eroding peat, enhancing carbon sequestration and removing drivers of degradation. Numerous blanket peatland restoration projects have now taken place and there is a growing support network for peatland practitioners through projects such as the Peatland Compendium in the UK (www.peatlands.org.uk) and the IUCN UK peatland programme (http://iucn-ukpeatlandprogramme.org). However, at present, there is little guidance or support available to ensure practitioners carry out effective blanket peatland restoration, nor a comprehensive understanding of the success of each restoration technique or how it may be quantified. The remainder of this paper aims to discuss the techniques used in the restoration of blanket peatlands and analyse current understanding of the success of each of these factors. Following this, we will consider the logistical challenges of carrying out multi-technique, landscape scale restoration. Finally we will consider our current understanding of the impact of blanket peat restoration on ecosystem services.

\subsection{Drain blocking techniques}

Blocking of drainage ditches is one of the most commonly reported practices used in blanket peatland restoration projects in the UK and Ireland (Holden et al., 2008b). On blanket peatlands most drain blocking has involved the placement of dams at regular intervals along the drain rather than fully infilling drains, a practice which is common on less topographically varied peatlands (Armstrong et al., 2009). Blanket peatland managers must adapt drain blocking techniques to the surrounding topographical conditions and the positioning of the ditch within the landscape. This may include placing blocks closer together on higher energy areas (steeper slopes or where discharge is greater) and blocking drains on upper hillslopes first to minimise pressure from flow accumulation on dams downslope. Armstrong et al. (2009) provided a comprehensive review of projects which have undertaken blanket peatland drain blocking in the UK and found that when practitioners considered the variable nature of blanket peat hydrology, dams were more likely to be successful.

A number of different materials can be used to block peat drains (Figure 2). Peat itself is the most popular material used in the UK (Armstrong et al., 2009). Using peat is economical, requires no transport onto site and dams can be easily tailored to the size of individual drainage ditches (i.e. wider and deeper eroded drains can be blocked without additional materials being brought on site). 
However, the creation of successful peat dams requires careful consideration. Peat must first be sourced to construct dams. Typically this is near to the dam site, such as from a borrow pit at the side of the channel or from within the drain itself. Less humified peat is best for the construction of dams (Armstrong et al., 2009). Sourcing peat for the dams is often difficult and can require deep borrow pits which are visually obtrusive and where vegetation cannot easily re-colonise. However, if the peat is pulled backwards from within the drain and contoured on the upslope side, producing a shallow slope on which vegetation is able to colonise, this obtrusion can be prevented. If necessary, the drain is reprofiled, where the steep edges of the drain are pulled into the drain and vegetation is redistributed to cover bare peat. This process forms a shallower channel profile, to further reduce the depth of the pool behind the dam. Deep pools are associated with poor vegetation colonisation (Armstrong et al., 2009) and natural peatland pools have been found to have higher $\mathrm{CH}_{4}$ output and lower $\mathrm{CO}_{2}$ uptake than topographically drier areas (Waddington and Roulet, 1996). Although further research is required to establish the role artificial pools have on climate forcing, these data suggest pool depth and area to a minimum when ditch blocks are created. This can be achieved by creating an overspill channel, which dissipates water into the surrounding vegetation, preventing further erosion of the peatland. It is essential that peat dams are keyed securely into the surrounding peatland. If peat plugs are used, where peat is simply scooped out and placed in the ditch, water will find weaknesses and the dam is likely to fail. The failure of peat dams will temporarily increase particulate organic carbon (POC) loads and reduce water quality in the area (Holden et al., 2008b) in some cases negating the ecosystem services provided by restoration works.

\section{INSERT FIGURE TWO HERE}

Although peat is the preferred material for drain blocking it cannot be used in all circumstances, particularly when a ditch has incised to the mineral layer, as undercutting will cause failure of the dam (Armstrong et al., 2009). In cases such as these, alternative materials have been used to block ditches in blanket peat including plastic piling, heather bales and wooden dams (Figure 2). In the UK, heather bales have been commonly used but these aim to trap and slowly accumulate sediment rather than rapidly block the ditch (Armstrong et al., 2009), as a result it is not expected that these blocks will have an immediate impact (Armstrong et al., 2010). However, recent increase in the cost of heather brash has reduced the use of heather bales in both ditch blocking and other restoration practices. In larger drainage ditches, channel sides are often reprofiled, this is thought to reduce energy and stream power within the ditch and, with blocking, reduce the efficiency of the drain.

\subsection{Gully blocking and reprofiling}

Gullies are closely associated with a decline in ecosystem service provision, such as carbon storage and accumulation (Evans and Lindsay, 2010) and water quality (Daniels et al., 2008a). Once gully incision has started it often quickly progresses via headward retreat (Bower, 1960) and the gully 
network can expand rapidly causing widespread peat erosion. To prevent further expansion of the gully network, gullies are often dammed from the most headward portion downward in order to trap sediment, slow down water flows and raise local water tables. Reprofiling of the sides of gullies also occurs in many places in an attempt to reduce gully side slope steepness to reduce erosion rates. These techniques sound similar to the ones described above which are used for drain blocking in blanket peat, but Evans et al. (2005) pointed out that gully systems form by geomorphological processes and that more variability in gully morphology and pattern can be observed in individual blanket peatlands than on artificial ditch networks. As a result, a more flexible approach to restoration must be taken than for ditch blocking.

Strategies for dealing with the variable morphological nature of gully systems should be guided by the geomorphological and hydrological processes forming them (Evans et al., 2005). Gully systems are dynamic, they do not only continually incise and grow, but are also able to naturally trap sediment and revegetate (Evans and Warburton, 2001). Natural blockage occurs as a result of peat blocks, produced by over steepening and collapse of gully sides, being deposited in areas where flow velocity has reduced or where they get jammed in narrow gully sections (Evans and Warburton, 2001). It has been suggested that techniques for damming gullies may be more successful if they follow the characteristics seen under natural recovery conditions (Crowe et al., 2008). Gully infilling occurs when blocks of peat impede drainage sufficiently to allow accumulation of re-deposited peat and colonisation of pioneering species such as Eriophorum (Crowe et al., 2008).

The UK peatland compendium found that of the six restoration projects surveyed which had blocked gullies, most used a combination of materials for blocking rather than a single material in isolation (Holden et al., 2008b); these materials included plastic piling, peat, wood, stone, heather bales and timber. On occasion, in gullied areas the surrounding peat is bare and restoration using machinery can be damaging to the fragile peat. In these conditions stone dams can be used (Figure 3b); where stone is gently placed in gully nick points using a very low-flying helicopter. When designing gully blocking strategies, the spacing and positioning of the blocks is an important consideration, as if dams are spaced too widely the pressure from flow accumulation will be great and a dam will fail. When blocks are spaced so that the base of the upslope block is level with the top of the downslope block, greater sediment accumulation and less scouring occurs (Evans et al., 2005). In addition to flow accumulation, consideration should be given to changes in surrounding geomorphology and peat or soil types which may increase flow accumulation or weaken blocks. For example, if a series of peat pipes exit into a gully system the additional flow may place more pressure on blocks and cause failure. Peat pipes can also erode and this can result in further gully development. As a result, some pipe blocking has recently been undertaken in the Yorkshire Dales, UK. Research is currently being carried out to assess the impacts of blocking pipes. 
Often gully sides have steep slopes and there are large areas of exposed bare peat which can be eroded and rapidly transported to the gully channel (for example Figure 3b). These areas are a source of POC (Evans and Warburton, 2007) and in addition to blocking gullies, reprofiling and vegetation on steep and bare gully sides is often undertaken to reduce the slope and susceptibility to erosion (similar to the ditch blocking process described in section 2.2). Following reprofiling, healthy vegetation from a donor site not connected to the gully, is used to cover bare peat on the reprofiled edge. Reprofiling and revegetating gully sides aims to reduce erosion, as it would be expected that this would decrease the connectivity of sediment and POC with the gully and stream network. Reprofiling such as this can be applied to other peatland features including artificial drainage channels and hagged areas. In some areas gully features are very wide and shallow, and neither blocking nor reprofiling will entirely restrict water flow. One possibility is to reduce stream flow by creating zones of deposition (Evans et al., 2005). This can be achieved by bunding or use of coir logs if stream power is low enough. In these areas, revegetation should be strongly encouraged as this will trap sediment and gradually encourage recovery of the gully system (Evans and Warburton, 2001).

\subsection{Bare peat stabilisation}

Areas of bare peat vary in size, geomorphological and topographical context and can be found in the form of large, flat, peat pan areas through to steep gully and hag edges. Reflecting this, a number of methodologies have been developed allowing adaptation to these scenarios. Although each methodology differs in tools and material requirements, they all follow the same basic principle to provide a protective layer to prevent further weathering and to slow the rate of erosion. Most erosion occurring on blanket peatlands is fluvial (Evans and Warburton, 2005) although wind-assisted splash is also common (Foulds and Warburton, 2007). Fluvial erosion can lead to further degradation such as the development of gullies. Ideally, stabilisation of bare peat is achieved by re-establishment of vegetation by seeding and the introduction of pre-grown seedlings known as plug plants. However, in many areas the flow of water, erosion and weathering of peat is too rapid to allow vegetation to reestablish without mitigation.

The aim of fully covering the peat surface is to provide a temporary protective cover and to establish a microhabitat in which vegetation can re-establish. Similar applications of protective mulch have been found to be successful in some continental bogs (Price et al., 1998; Chimner, 2011; Rochefort et al., 2003). On blanket peat, coverage is achieved using either heather brash or geo-textiles spread over the bare peat surface (Moors for the Future Partnership., 2012d). Heather brash spreading involves the application of heather, which has been cut locally, to gently sloping bare peat surfaces (Figure 4a). In addition to providing a protective coverage, heather brash contains seed which facilitates the reestablishment of vegetation. In order to maximise the seed content, heather brash is often cut in the early winter and is 'double chopped' into shorter lengths to allow it to remain on the peat surface 
(Yorkshire Peat Partnership, 2010). If brash is spread too thick the lack of light reaching the peat surface will prevent re-establishment of vegetation.

Geo-jute is a biodegradable textile made from natural fibre which is attached to a bare peat surface using metal pins (Figure 4b). Geo-jute is able to sustain more exposed conditions and steeper slopes than brash. It is typically used on gully sides or hagged areas (Figure $4 \mathrm{~b}$ ), where vegetative coverage via reprofiling is not an option as both peat and the surrounding vegetation is in poor condition (e.g. Worrall et al., 2011). Weather conditions following the application of geo-jute are important for success. Rain soon after application will push the geo-jute into the peat surface and stabilise it, whilst a period of frost will produce needle ice and frost heave which will extract the securing pins and push up the material so it is no longer flush with the peat surface.

\section{INSERT FIGURE FOUR HERE}

Where bare peat is threatened by weathering and erosion a combination of both heather brash and geo-jute can be applied. In the northern hemisphere this is often on exposed north facing slopes, which are more likely to suffer from frost heave. Both geo-jute and heather brash will eventually biodegrade. By this point it is important that vegetation has re-established enough to sustain itself and protect the peat. Often in degrading peatlands vegetation colonisation is slow, probably because atmospheric pollution and the resulting reduced $\mathrm{pH}$ levels restrict the growth of blanket peatland vegetation such as Sphagnum (Ferguson et al., 1978).

On some areas of bare peat, overland flow is rapid and gullies may begin to incise unless contained. In areas such as this, water flow is too rapid to allow vegetation re-establishment and techniques such as heather brash and geo-jute cannot be sustained. The appropriate placing of either heather bales (Figure 4c) or coir logs (Figure 4d) can be used to restrict the flow of water. Heather bales are used to restrict flow in narrow areas of erosion, such as between isolated areas of vegetation or in nick points in small gullies. In areas where overland flow occurs over broad areas, longer coir logs are preferred as these are more manoeuvrable and faster to position in situ than heather bales. After a period of monitoring, if concentrated overland flow has been restricted sufficiently then heather brash can be used to protect the bare peat surface and to promote re-vegetation.

Often in bare peatlands the seed bank is low, $\mathrm{pH}$ levels are very acidic, the peat surface can suffer rapid desiccation or frost heave (Evans and Warburton, 2007) and as a result vegetation does not readily establish following stabilisation. In order to encourage reestablishment, bare areas of blanket peatland are often limed to raise peat $\mathrm{pH}$ levels to those suitable for the establishment of vegetation (Yorkshire Peat Partnership., 2011). After approximately six weeks, fertiliser and nurse grass seed is applied to the bare or stabilised peat (Moors for the Future Partnership., 2012a). Typical species include Agrostis capillaris, Festuca rubra and Lollium perenne (Yorkshire Peat Partnership, 2011), which are applied due to their ability to grow rapidly and maintain ground cover, until more typical 
peatland flora have time to establish (Yorkshire Peat Partnership., 2011). Following the establishment of a nurse-crop, native plants such as Calluna vulgaris, Erica cinerea, Eriophorum vaginatum and E. angustifolium are introduced via pre-propagated 'plug' plants or gathered seed (Moors for the Future Partnership., 2012b). In some UK blanket peatlands the presence of Sphagnum is very low, which is thought to be as a result of historic atmospheric pollution (Smart et al., 2010). Some peatland restoration projects are now spreading Sphagnum encased within protective beads in an attempt at reintroduction (Moors for the Future Partnership., 2012c). However, this process is still experimental and its success is not known. In areas of bare cut-over peatland in Canada, Sphagnum has been established by preparing the disturbed peat surface (e.g. by milling it) to more closely reflect the ecohydrological and hydrophysical properties of an undamaged peat surface before Sphagnum is introduced (Waddington et al., 2011) and protective mulch is then added. This preparation may also be applicable on sloping blanket peatlands, however some care is needed in sloping environments where erosion can be exacerbated and Sphagnum can be washed away.

\subsection{Restoration logistics}

Careful consideration must be given to the logistics and type of machinery used when carrying out peatland restoration to avoid causing additional damage to the peatland. Many restoration projects involve the regular movement of machinery across a blanket peatland, for example to refuel excavators. This can place constant pressure upon the blanket peatland and result in gradual compression and damage to the peat and vegetation. In worst case scenarios, machinery can become stuck or even buried. To avoid damage, machinery with low ground pressures $(<2.5$ psi) should be used to carry out blanket peat restoration and use multiple access routes. Access and susceptibility to damage is variable across a blanket peatland and is determined by bulk density, wetness and vegetation cover. Before heavy machinery is used, an on-site a survey should be carried out, this will allow machinery operators to avoid causing damage to the most vulnerable areas. If significant quantities of materials need to be brought onto site, such as heather bales, plastic piling and heather brash, a helicopter can be used to rapidly transport materials with no damage caused to the intended restoration site.

\section{Impacts}

In order to ensure appropriate use of restoration funds, investigations into how restoration can be carried out most effectively are essential. Stakeholders are increasingly required to justify any investment by examining the effects of restoration upon ecosystem services. To date, most research and monitoring of restoration has focused upon ditch blocking and there is considerably more understanding of impacts from this restoration practice than any other in blanket peatlands (GrandClement et al., 2013). Table 1 provides an overview of the response of ecosystem service features to restoration practices and an indication of where understanding and data are lacking. It is clear that 
there is a paucity of research into the impacts of gully blocking, bare peat stabilisation and seed/lime/fertiliser approaches. This section aims to discuss the evidence base currently available on impacts of restoration on ecosystem services, including stream peak flow, water table and hydrological processes, water quality and sediment delivery to water bodies, ecology and carbon fluxes. Where data are not available, the potential impact will be hypothesised given current understanding of peatland processes and response to other restoration activities.

\section{INSERT TABLE ONE HERE}

\subsection{Stream peak flow}

Reduced stream peak flow and longer lag times are often cited as a benefit of restoration practices (e.g. Bevan et al., 2004), as flood risk may be reduced (Bain et al., 2011). However, there has been very little measurement of peak flow response to blanket peatland restoration. If drainage within a peatland is active, theoretically overland flow will be rapidly intercepted and the drains will act as a conduit, possibly enabling shorter lag times and higher peak-flows following a period of rainfall (Holden et al., 2004). However, the degree to which it does this can be variable dependant on topographic configuration of the drainage network (Holden et al., 2004). For example, using a simple model, Lane and Milledge (2012) have shown that drains may not shorten lag times because flow paths may actually be longer via some drain networks than they could be via overland flow. Consequently, evaluating peak flow response to blocking can be very difficult and requires an understanding of peak flow response in an individual peatland before blocking. Wilson et al. (2011b) measured stream discharge following storm events both before and after blocking of drainage ditches and found that, at a local scale, peak flows were reduced following blocking. However, these results may not be fully representative of other drained and restored blanket peatlands. Ballard et al. (2012) adapted a model developed to simulate the hydrological response to drainage and drain blocking in blanket peatlands. They concluded, in line with Holden et al (2008b) and Lane and Milledge (2012), that surface roughness was probably a more important variable controlling stream lag times and peak flows than blocking drains. Thus, in most cases, a transition from bare peat to vegetated peat would yield greater storm flow changes in the river than blocking peatland drains. In some cases reprofiling drainage ditches, which will increase the surface roughness of the drain channel, in addition to simply blocking, may have an additional benefit for peak flow reduction.

There is currently no research which considers the stream flow response to stabilisation and revegetation restoration practices. However, Holden et al. (2008a) demonstrated that overland flow velocities were significantly lower on vegetated ground than on bare peat, and particularly so when Sphagnum dominated. This research indicates that overland flow characteristics may change when vegetation becomes established following stabilisation. Moreover, Grayson et al. (2010) empirically showed that a well vegetated catchment had a lower peak flow than the same catchment with a higher 
proportion of bare peat. Consequently, areas of bare peat restoration may facilitate reduced flood risk, although the spatial extent of bare peat restoration needed for this to occur is unknown.

Understanding peak flow response is complex for all degradation and restoration features and can vary greatly according to the topographic configuration of individual blanket peatlands. It may also vary depending on the scale of restoration. As a result, it is difficult to generically determine whether restoration is beneficial in reducing flood risk. However, moorland managers may still wish to determine how degradation is impacting peak flow and whether restoration may be beneficial on specific peatlands. Adapted versions of models such as those used by Lane and Milledge (2012) and Ballard et al. (2012) or the model under development by Jihui Gao et al (pers com) at the University of Leeds may facilitate a meaningful understanding of peak flow response, both before and after restoration for individual peatlands. Development of models such as these should be considered a research priority in this area. Modelling will also need to address the issue of downstream propagation of flood reductions. While it may be possible to demonstrate flood peak benefits of peat restoration at the hillslope or small headwater catchment scale, further modelling work is required to establish under what circumstances such benefits can be realised downstream in larger catchment systems.

\subsection{Water table and hydrological processes}

The restoration of water table has been cited as a major driver for blocking drainage ditches (Holden et al., 2008b). This is predominantly because water table level and its characteristics are often thought to be associated with a number of ecosystem services (Armstrong et al., 2009), including gaseous carbon fluxes, the production of water colour and DOC, and hydrological flow paths (Reed et al., 2013). Most studies have shown that drain blocking creates shallower water tables in the surrounding peat (Worrall et al., 2007; Wilson et al., 2010). However, water table response to drainage is variable and dependent on the surrounding topography (Holden et al., 2006), drain position in the catchment (Holden, 2005b) and distance from the drain (Dunn and Mackay, 1996). In turn, the degree of water table recovery following ditch blocking could also be spatially and topographically variable. Consequently, in order to accurately represent water table response to blocking, monitoring strategies must take spatial variability into account. Holden et al. (2011) investigated comparative transects across a system and used spatial weighting to derive mean site water table depths, finding spatial variability in water table levels associated with position relative to drain. Wilson et al. (2010) included both large and small scale spatial and topographic variability as part of their sampling design. Locally, Wilson et al. (2010) showed that, as expected, the areas with a similar elevation to the nearest dam, and those locations with a larger contributing area had a better water table response to blocking. At a landscape scale, Wilson et al. (2010) found that their four monitored catchments had significant 
differences in water table recovery, which they suggest may have been related to differences in peat structure, catchment size and topography.

Ditch blocking causes rapid change in the hydrological characteristics within the ditch (Worrall et al., 2007), such as reduced stream power and increased pooling of water. However, timescales of hydrological change within the blanket peat mass may not occur at the same rate. Water table response to blocking can be slow; Wilson et al. (2010) found water tables took over a year to respond to blocking and Holden et al. (2011) identified that neither water table levels nor hydrological behaviour had similar characteristics to a comparative undisturbed site six years after restoration. This slow response is thought to be related to changes in the peat structure, hydrological conductivity and vegetation observed following drainage (Holden et al., 2006; Ramchunder et al, 2009; Wallage and Holden, 2011), which in turn impacts upon the hydrological characteristics of peat (Ballard et al., 2012). However, if the surrounding ecology begins to respond to small changes in hydrology caused by ditch blocking, ecohydrological feedbacks may begin to occur, which in turn will impact upon surface hydrology, peat physical properties and therefore recovery of water table levels.

Ecohydrological feedbacks such as these may happen over decadal to centennial time scales. Due to the relatively short period for which ditch blocking has been carried out, and the often restricted time available for monitoring, as a result of funding restrictions, it is difficult to characterise long-term responses such as these.

There is little known about water table levels in gullied blanket peatlands, beside work by Allott et al. (2009) who monitored severely degraded peats in the Peak District, UK. Allott et al. (2009) identified that whilst water table drawdown was only obvious locally to two meters either side of gully edges, water tables were generally less stable and considerably lower in gullied catchments than in comparative intact catchments. Dams placed in gullies are rarely level with the peat surface, because gullies are often so deep and wide that creating large dam pools would be a danger to humans and livestock. As a result water will never pool enough to restore original water table levels. However, if the dam is gradually built up over time as the gully begins to infill with sediment, water table levels may slowly begin to rise. This process may take a considerable period of time and therefore will require both long-term repeated intervention and long-term monitoring.

\subsection{Dissolved organic carbon and water colour}

Reducing DOC production and subsequently export is an important motivation for peatland restoration, particularly for water companies who seek to control or even reverse the increasing trend of DOC/water colour in their potable water supplies via catchment management. Most studies which have monitored DOC following restoration have focussed on ditch blocking and an outline of each of these studies is provided in Table 2. In general, these studies suggest that ditch blocking leads to reductions in DOC concentration and export. However, the sampling strategies and techniques used to 
monitor DOC response vary, so that each study deals with different temporal and spatial scales. The processes causing change in DOC production and export may alter over extended timescales. At present little is known about longer-term response to blocking. It would also be expected that, akin to water table response, there are spatial and temporal controls on DOC production and delivery. This means similar ditch blocking intervention on differing sites may not always result in the same outcomes. This variability in response was observed by Armstrong et al. (2010) who measured DOC concentrations at several blocked and unblocked sites across the UK. Armstrong et al. (2010) also found little difference between the block material used and the amount of water colour within ditches nationally; however, more controlled investigation is required in order to understand whether different types of blocks have an influence on DOC concentrations. Very few studies exist which examine DOC concentrations from either blocked gullies or stabilised bare peat. Worrall et al. (2011) measured DOC export from bare, restored and control vegetated plots in the Peak District, UK, and found very little difference in export. However, this study was temporally limited, with two years of monitoring. At present no work has been published which considers DOC export response to stabilisation and gully blocking over longer timescales. Further work is needed in this area, particularly if water companies continue to have interest in such restoration strategies.

One concern may be that in areas with high historic atmospheric sulphate deposition a slight raising of the water table associated with gully blocking may result in an increase in DOC release (hence the upwards arrow on Table 1 associated with gully blocking). This is because oxidation (associated with deeper water tables and open gully faces) of stored sulphur to sulphate leads to an increase in acidity and a reduction in the solubility of DOC (Clark et al., 2005). Daniels et al. (2008b) identified that streams draining catchments with dense network of gullies had higher concentrations of sulphate and lower concentration of DOC than those draining more intact peatland catchments. Therefore, rewetting gullies in sulphur polluted areas is likely to lead to a reduction of sulphate to sulphur and a decrease in acidity, which could potentially increase DOC solubility and thus stream water DOC concentrations. This is an example of where the same restoration technique might have a different impact on some water quality ecosystem services in one peatland site compared to another, depending on its atmospheric sulphur pollution history.

\section{INSERT TABLE TWO HERE}

\subsection{Sediment and particulate organic carbon}

The blockage of drainage ditches using dams is thought to moderate POC export by reducing the area of bare peat and its connectivity with the downstream hydrological network (Ramchunder et al., 2012). Holden et al. (2007a) found sediment export was 54 times lower from drains with ditch blocking than unblocked drains, even when the quality of the dams was low. However, our own recent 
unpublished research (Bell, 2011) has revealed reduction in POC may not be immediate, as sediment already mobilised prior to blocking and now stored within stream channels is slowly reworked out of the system. If stream bank erosion, which existed before restoration, also naturally occurs at a high frequency then such sediment mobilisation may mask reductions in sediment delivery from drain blocking upstream. Wilson et al. (2011a) investigated POC concentrations before and after blocking, they found that concentrations were significantly lower in streams following blocking, but did not scale up their data due to the largely unpredictable event-based nature of POC production. As is the case for DOC, it is very likely that a significant proportion of the flux occurs during a few high flow events. Therefore, monitoring programmes need to be able to capture storm response when assessing the role of management interventions on aquatic carbon fluxes (Holden et al., 2012a; Clark et al., 2007).

Evans et al. (2005) assessed the ability of dam materials to accumulate sediment and restrict POC loss within gullies. In this study, it was found wooden and stone blocks were the best at entraining sediment, whilst plastic piles proved less effective and could be disturbed by frost heave (Evans et al., 2005). Evans et al. (2005) provided the only empirical study of gully blocking techniques; they suggest further research is needed over longer time scales, in a broader range of gully types with a variety of topographic conditions in order to better understand impact of gully blocking.

Evans et al. (2006) found that in blanket peatlands, where varying topography facilitates overland flow and erosion, POC could move freely and was readily lost in catchments with sparse vegetation. Vegetation considerably reduces overland flow velocities and entrains sediment (Holden et al., 2008a). Consequently, if stabilisation practices are successful in establishing vegetation, connectivity with the surrounding hydrological network will be reduced and it would be expected that POC export will decline. This hypothesis is supported by Worrall et al. (2011) who found POC losses were considerably higher on bare peat areas than sites which had been restored using heather brash.

\subsection{Ecology}

Blanket peatlands are listed as an EU and UK Biological Diversity Action Plan priority habitat and are of high global importance (JNCC, 2008). As a result, restoring pre-drainage ecological conditions are commonly cited as one of the primary reasons for ditch blocking (Holden et al., 2008b). Despite this, there is a paucity of studies which consider terrestrial or aquatic ecological response to blocking. Aquatic fauna form an important component of upland ecosystems, however, Ramchunder et al. (2012) is the only study which considers their response to drain blocking. Aquatic macro-invertebrate communities were sampled from streams with drained, blocked and intact peatland catchments. Macro-invertebrate community compositions and taxonomic richness in streams with ditch blocked catchments were more comparable to those draining intact catchments than catchments with open ditches. As a result, this study suggests that blocking improves aquatic ecology toward that of a more 
natural system. Drain blocking has also been shown to improve crane fly populations by Carroll et al. (2011), who carried out a landscape scale study into abundance of crane fly on four comparison blocked and unblocked sites. However, this study was only carried out over a two year period and data were recorded following only three emergence seasons. Further data are needed to investigate whether these trends are continued over longer time scales. To date no research has been carried out considering the aquatic ecological response to gully blocking and stabilisation practices. However, Ramchunder et al. (2012) identified that reduced suspended sediment significantly improved macroinvertebrate ecology. Consequently, if stabilisation and gully blocking are successful in reducing POC loads in streams downstream of an eroding catchment, an additional benefit of stabilisation and gully blocking may be improvement in aquatic biodiversity.

Peatland vegetation is important for a wide range of functions including hydrological processes (Holden et al., 2008a), peat accumulation (Clymo, 1984) and gaseous flux (Strack et al., 2006). Nonetheless, only Bellamy et al. (2012) have considered vegetation response to peatland drain blocking. Vegetation composition surrounding unblocked drains and drains which had been blocked for between five and eleven years was surveyed. Bellamy et al. (2012) found only drains blocked for the greatest period of time, in one of the two studied catchments, had vegetation compositions indicative of a recovering peatland. Vegetation recovery following blocking may lag hydrological response, consequently these slow response times may reflect this. Peatland managers should take lag time into account when assessing the success of restoration works on biodiversity.

Gully systems have been dated to 2000 years BP in some areas of the UK (Ellis and Tallis, 2001; Tallis, 1987). As a result, in active gullies where the water table has been drawn down for an extended period of time, the surrounding vegetation may have been adapted to dry conditions for several centuries. Consequently, there may be few wet tolerant species, which are typically associated with healthy blanket peatlands, in the local area to colonise restored areas. Therefore, a catchment scale vegetation response to gully blocking may have an even greater time lag following blocking than conventional ditch blocking. Broadly assessing the recovery of vegetation in gullies following blocking can also be difficult, because the vegetation composition prior to restoration is very variable between gully systems (Connor, 2013). Thus, restoration projects must monitor success on a site by site basis.

Often stabilisation sites are seeded with a non-native plant mix and limed and fertilised to ensure the establishment of vegetation (Worrall et al., 2011). Although this activity may cause stabilisation of the peat surface, the resulting community of species will not be typical of a blanket peatland. If the intention of restoration is to preserve blanket peatland ecology and encourage peat accumulation it is important to ensure that blanket peatland communities, which are adapted to low nutrient availability (Bellamy et al., 2012), are able to re-establish following intervention. At present it is not known how blanket peatland ecology will respond to lime, seed and fertilisation in the long term and further 
research is required in order to understand the impact of stabilisation practices on blanket peatland terrestrial ecology.

\subsection{Climate forcing}

Atmospheric fluxes form an important component of the peatland carbon balance and contribute directly to climate change. Peatlands can either have a positive or negative impact on global climate forcing, depending on the forms and rates of carbon fluxes. Decay rates in the aerated (oxic) zone are thousands of times greater than those in the absence of oxygen (e.g. Clymo, 1983; Frolking et al., 2002). Therefore, a deepening of the oxic zone caused by lowering of water table (e.g. from gully erosion or drainage ditches) can cause large increases in rates of $\mathrm{CO}_{2}$ emissions from peatlands and a loss of carbon sink function (Dirks et al., 2000). However, a lowering of the water table may result in less $\mathrm{CH}_{4}$ emissions. Change in peatland conditions brought about by restoration will inevitably have an impact upon the amount and type of gaseous carbon fluxes. Typically, it is thought that $\mathrm{CH}_{4}$ emissions will increase as a result of rewetting and $\mathrm{CO}_{2}$ emissions will decrease due to a decline in aerobic conditions. Although $\mathrm{CH}_{4}$ normally makes up a smaller proportion of a peatland carbon balance than $\mathrm{CO}_{2}\left(\mathrm{CH}_{4}\right.$ losses tend to be 3-5\% of net $\mathrm{CO}_{2}$ exchange; Baird et al., 2009), it has significantly more global warming potential (GWP). As a result it is important to monitor the change in balance between $\mathrm{CO}_{2}$ and $\mathrm{CH}_{4}$ fluxes before and after restoration.

Baird et al. (2009) review current understanding of restoration impacts on methane emissions and how such emissions affect the carbon sink function. Using an extensive search of published and grey literature, a questionnaire to the peatland scientific community, and a workshop with UK scientists they found that, across all peatland types, very little work has been done on this topic. Nonetheless despite the lack of research available, some tentative general conclusions were based on the evidence compiled. Baird et al. (2009) suggest restoration does not necessarily lead to a peatland becoming a carbon sink, either in terms of a simple carbon balance or in terms of its effect on global warming potential. However, restored peatlands tend to have a smaller GWP than unrestored damaged peatlands and restoration is therefore generally beneficial from a global warming point of view. Despite this, there are still examples of restored peatlands that have higher global warming potential than unrestored peatlands (e.g. Waddington and Day, 2007) and response seems to depend on the nature of damage and the type of restoration.

Rowson et al. (2010) recorded gaseous fluxes from the blanket peat surface located between two blocked drains and reported an export of between +9.3 and $+40.7 \mathrm{MgC} \mathrm{km}^{-2} \mathrm{yr}^{-1}$ during the year following blocking. These fluxes were recorded soon after blocking and therefore represent a shortterm response to change and not long-term impact. Although these data are useful in forming carbon budgets, it is not possible to draw conclusions about the gaseous carbon flux response to drain blocking based on these data alone, as no control was measured. Roulet et al. (2007) and Dinsmore et 
al. (2013) have demonstrated that annual peatland carbon budgets are strongly influenced by climate and can vary significantly from year to year and as Rowson et al. (2010) reports values for only one year it is difficult to separate these results from the influence of climate. Green et al. (2011) used mesocosm laboratory experiments to determine how ditch blocking may impact the global warming potential of a peatland and $\mathrm{CH}_{4}$ emissions. They found that the global warming potential (GWP) within simulated drainage ditch conditions was positive following blocking. However, there was no comparison with an unrestored scenario and consequently it is not possible to determine whether the GWP of unblocked drains is higher. Green et al. (2011) also found release of $\mathrm{CH}_{4}$ was influenced by plant type, with ditches colonised by Sphagnum releasing less than those colonised by sedge and Ericaceous shrub. From this outcome, Green et al. (2011) suggests that Sphagnum spread following restoration should be encouraged if GWP is to be reduced as much as possible. Clearly, considerably more long term studies of peatland carbon fluxes, both before and after blocking, are needed if understanding of the relationship between ditch blocking and carbon fluxes is to be gained.

Bare peat will always be a net exporter of gaseous carbon as there is no input from photosynthesis. Consequently, routes of gaseous carbon flux will change considerably following stabilisation, as both photosynthesis and respiration will increase as vegetation is established. However, the magnitude and routes of these changes are not known. Particular consideration must also be given to the application of lime and fertiliser to peatlands restored by stabilisation, as a result of changes in peat biogeochemistry. Biasi et al. (2008) monitored $\mathrm{CO}_{2}$ release following the application of lime, finding little change in $\mathrm{CO}_{2}$ export as a result of increased peat decomposition, but an elevated $\mathrm{CO}_{2}$ export as a result of the breakdown of lime in the short term following application. There is a lack of data considering impact of stabilisation on climate forcing and long term monitoring projects should be given a priority if stabilisation and bare peat restoration continues to become a common restoration practice.

Following the addition of peatland restoration into the Kyoto Protocol (Joosten, 2012), carbon markets are likely to become an increasingly important funding source for peatland restoration (Grand-Clement et al., 2013). In order to secure funding, moorland managers are going to need to justify ditch blocking and other restoration approaches as a carbon management technique. As a result, there is an urgent need for carbon flux studies at broader spatial scales, over longer timescales and with comparative datasets from unrestored sites.

\section{Conclusion}

Rapid progress has been made since the turn of the century in developing methodologies for the restoration of degraded blanket peatlands. Many techniques are now used to restore a range of degradation features and address impact on several ecosystem services. However, there has been little 
formal communication of the techniques used and their success. Using a wide range of sources, this paper has discussed how restoration techniques are carried out on blanket peatlands and what is known about the impact of each.

This review has highlighted that spatial and temporal variability causes considerable differences in development of degradation features on blanket peatland. As a result, the condition, stage and type of degradation differ both within and between individual restoration sites. Consequently, designing restoration strategies can be complex and restoration techniques used must be tailored to suit the needs of the peatland. Spatial and temporal variability also influence how degradation features impact upon ecosystem services; for example, some areas may be subject to greater water table drawdown or experience more active erosion. This variability may also explain inconsistency in response to many restoration practices (such as Wilson et al., 2011 and Armstrong et al., 2010). Peatland managers may be able to use this variability to their advantage, by identifying areas that are most impacted by degradation and those which are more likely to respond to restoration. This would allow targeted, informed restoration and more efficient use of funding. Additionally, to allow meaningful investigation into the impact of restoration, results must be interpreted within the context of the timescales and the topographic conditions monitoring occurred within in. Sampling strategies must also be designed with full consideration of the spatial variability in topographic, hydraulic and ecological conditions within the area.

Although there has been substantial development in understanding the impact of certain restoration practices on ecosystem services, such as drain blocking, there are still a large number of areas where further work is needed. Table 1 highlighted major gaps and areas of uncertainty that should be prioritised for research. There has been little research carried out considering impacts of both gully blocking and bare peat stabilisation techniques on revegetation or wider ecosystem services. This is remarkable given the huge expense of such restoration programmes and their increased use. If more informed management decisions are to be made and if restoration funding is to be appropriately spent, there is an urgent need for increased monitoring to be put into place.

\section{Acknowledgements}

This paper was written as part of a Knowledge Transfer Partnership funded by the Technology Strategy Board, Natural Environment Research Council and Dinsdale Moorland Services Ltd (partnership number 8086). We are grateful to the North Pennines AONB Partnership (@ North Pennines AONB Partnership) (Figure 1), Alona Armstrong (Figure 2c and 2d) and Dinsdale Moorland Services Ltd (Figures 3 and 4) for providing permission to publish photographs. 


\section{References}

Albertson, K., Aylen, J., Cavan, G., McMorrow, J., 2010. Climate change and the future occurrence of moorland wildfires in the Peak District of the UK. Climate Research 45, 105-118.

Allott, T.E.H., Evans, M.G., Lindsay, J.B., Agnew, C.T., Freer, J.E., Jones, A., Parnell, M., 2009. Water tale levels in Peak District blanket peatlands Report number 17. Moors for the Future Partnership, Bakewell. .

Anderson, P., Tallis, J.H., Yalden, D.W., 1997. Restoring moorland: Peak District Moorland Management Project, Phase III report. Peak Park Joint Planning Board. Bakewell.

Armstrong, A., Holden, J., Kay, P., Foulger, M., Gledhill, S., McDonald, A.T., Walker, A., 2009. Drain-blocking techniques on blanket peat: A framework for best practice. Journal of Environmental Management 90, 3512-3519.

Armstrong, A., Holden, J., Kay, P., Francis, B., Foulger, M., Gledhill, S., McDonald, A.T., Walker, A., 2010. The impact of peatland drain-blocking on dissolved organic carbon loss and discolouration of water: results from a national survey. Journal of Hydrology 381, 112-120.

Bain, C.G., Bonn, A., Stoneman, R., Chapman, S., Coupar, A., Evans, M., Gearey, B., Howat, M., Joosten, M., Keenleyside, C., Labadz, J.C., Linsday, R., Littlewood, N., Lunt, P., Millar, C.J., Moxley, A., Orr, H., Reed, M.S., Smith, P., Swales, W., Thompson, D.B.A., Thompson, P.S., Van der Noort, R., Wilson, J.D., Worrall, F., 2011. IUCN UK Commision of Inquiry on Peatlands. Peatland Programme, Edinburgh.

Baird, A.J., Holden, J., Chapman, P.J., 2009. Literature review of emissions of methane from peatlands. Project code: SP0574. Final report for Defra. 54pp.

Ballard, C.E., McIntyre, N., Wheater, H.S., 2012. Effects of peatland drainage management on peak flows. Hydrology and Earth System Sciences 16, 2299-2310.

Bell, M.J., 2011. Effects of drainage and drain-blocking in a UK upland peatland on fluvial organic carbon loss during storm events. Unpublished Msc Thesis, University of Leeds.

Bellamy, P.E., Stephen, L., Maclean, I.S., Grant, M.C., 2012. Response of blanket bog vegetation to drain-blocking. Applied Vegetation Science 15, 129-135.

Belyea, L.R., 1996. Separating the effects of litter quality and microenvironment on decomposition rates in a patterned peatland. Oikos $77,529-539$.

Belyea, L.R., Clymo, R.S., 2001. Feedback control of the rate of peat formation. Proceedings of the Royal Society of London Series B-Biological Sciences 268, 1315-1321. 
Biasi, C., Lind, S.E., Pekkarinen, N.M., Huttunen, J.T., Shurpali, N.J., Hyvönen, N.P., Repo, M.E., Martikainen, P.J., 2008. Direct experimental evidence for the contribution of lime to CO2 release from managed peat soil. Soil Biology and Biochemistry 40, 2660-2669.

Bower, M.M., 1960. Peat erosion in the Pennines. Advancement of Science 64, 323 - 331.

Carroll, M.J., Dennis, P., Pearce-Higgins, J.W., Thomas, C.D., 2011. Maintaining northern peatland ecosystems in a changing climate: effects of soil moisture, drainage and drain blocking on craneflies. Global Change Biology 17, 2991-3001.

Chapman, P., 1993. Caves and Cave Life. Collins.

Charman, D.J., 2002. Peatlands and environmental change. Wiley, Chichester.

Chimner, R., 2011. Restoring sedges and mosses into frost heaving iron fens, San Juan Mountains, Colorado Mires and Peat 8, 1 - 8 .

Clark, J.M., Billett, M.F., Coyle, M., Croft, S., Daniels, S., Evans, C.D., Evans, M., Freeman, C., Gallego-Sala, A.V., Heinemeyer, A., House, J.I., Monteith, D.T., Nayak, D., Orr, H.G., Prentice, I.C., Rose, R., Rowson, J., Smith, J.U., Smith, P., Tun, Y.M., Vanguelova, E., Wetterhall, F., Worrall, F., 2010. Model inter-comparison between statistical and dynamic model assessments of the long-term stability of blanket peat in Great Britain (1940-2099). Climate Research 45, 227-U281.

Clark, J.M., Chapman, P.J., Adamson, J.K., Lane, S.N., 2005. Influence of drought-induced acidification on the mobility of dissolved organic carbon in peat soils. Global Change Biology 11, 791-809.

Clark, J.M., Lane, S.N., Chapman, P.J., Adamson, J.K., 2007. Export of dissolved organic carbon from an upland peatland during storm events: Implications for flux estimates. Journal of Hydrology $347,438-447$.

Clymo, R.S., 1983. Peat, in: Gore, A.J.P. (Ed.), Ecosystems of the World 4A, Mires: swamp, bog, fen and moor. Elsevier, Oxford, pp. 159-224.

Clymo, R.S., 1984. The limits to peat bog growth. Philosophical Transactions of the Royal Society of London Series B-Biological Sciences 303, 605-654.

Clymo, R.S., 1987. The ecology of peatlands. Scientific Progress 71, 593 - 614.

Connor, A., 2013. An Investigation into the Revegetation Success of Artificially Blocked Gullies. Unpublished MSc Dissertation, University of Leeds.

Cooper, A., McCann, T., 1995. Machine peat cutting and land-use change on blanket bog in northernIreland. Journal of Environmental Management 43, 153-170. 
Crowe, S.K., Evans, M.G., Allott, T.E.H., 2008. Geomorphological controls on the re-vegetation of erosion gullies in blanket peat: implications for bog restoration. Mires and Peat 3,1 - 14 .

Cruickshank, M.M., Tomlinson, R.W., Bond, D., Devine, P.M., Edwards, C.J.W., 1995. Peat extraction, conservation and the rural economy in Northern-Ireland. Applied Geography 15, 365-383. Daniels, S.M., Agnew, C.T., Allott, T.E.H., Evans, M.G., 2008a. Water table variability and runoff generation in an eroded peatland, South Pennines, UK. Journal of Hydrology 361, 214-226.

Daniels, S.M., Evans, M.G., Agnew, C.T., Allott, T.E.H., 2008b. Sulphur leaching from headwater catchments in an eroded peatland, South Pennines, U.K. Science of the Total Environment 407, 481496.

Davies, G.M., Gray, A., Hamilton, A., Legg, C.J., 2008. The future of fire management in the British uplands. International Journal of Biodiversity Science \& Management 4, 127-147.

Dinsmore, K.J., Billett, M.F., Dyson, K.E., 2013. Temperature and precipitation drive temporal variability in aquatic carbon and GHG concentrations and fluxes in a peatland catchment. Global Change Biology 19, 2133-2148.

Dirks, B.O.M., Hensen, A., Goudriaan, J., 2000. Effect of drainage on CO2 exchange patterns in an intensively managed peat pasture. Climate Research 14, 57-63.

Dunn, S.M., Mackay, R., 1996. Modelling the hydrological impacts of open ditch drainage. Journal of Hydrology 179, 37-66.

Ellis, C.J., Tallis, J.H., 2001. Climatic control of peat erosion in a North Wales blanket mire. New Phytologist 152, 313-324.

Evans, M., Allott, T., Holden, J., Catherine, F., Bonn, A., 2005. Understanding Gully Blocking in Deep Peat, Moors for the Future report No 4, Castleton <http://www.moorsforthefuture.org.uk/sites/default/files/documents/MFF\%20RR04\%20\%5BMain\%5 D\%20Evans\%20M\%202005\%20Understanding\%20gully\%20blocking\%20in\%20deep\%20peat.pdf>.

Evans, M., Lindsay, J., 2010. Impact of gully erosion on carbon sequestration in blanket peatlands. Climate Research 45, 31-41.

Evans, M., Warburton, J., 2001. Transport and dispersal of organic debris (peat blocks) in upland fluvial systems. Earth Surface Processes and Landforms 26, 1087-1102.

Evans, M., Warburton, J., 2005. Sediment budget for an eroding peat-moorland catchment in northern England. Earth Surface Processes and Landforms 30, 557-577.

Evans, M., Warburton, J., 2007. Geomorphology of upland peat: erosion form and landscape change. Wiley-Blackwell, Chichester. 
Evans, M., Warburton, J., Yang, J., 2006. Eroding blanket peat catchments: Global and local implications of upland organic sediment budgets. Geomorphology 79, 45-57.

Farrell, C.A., Doyle, G.J., 2003. Rehabilitation of industrial cutaway Atlantic blanket bog in County Mayo, North-West Ireland. Wetlands Ecology and Management 11, 21-35.

Ferguson, P., Lee, J.A., Bell, J.N.B., 1978. Effects of sulphur pollutants on the growth of Sphagnum species. Environmental Pollution (1970) 16, 151-162.

Foulds, S.A., Warburton, J., 2007. Significance of wind-driven rain (wind-splash) in the erosion of blanket peat. Geomorphology 83, 183-192.

Frolking, S., Roulet, N.T., Moore, T.R., Lafleur, P.M., Bubier, J.L., Crill, P.M., 2002. Modeling seasonal to annual carbon balance of Mer Bleue Bog, Ontario, Canada. Global Biogeochemical Cycles 16, 10.1029/2001GB001457.

Gallego-Sala, A.V., Colin Prentice, I., 2012. Blanket peat biome endangered by climate change. Nature Clim. Change advance online publication.

Grand-Clement, E., Anderson, K., Smith, D., Luscombe, D., Gatis, N., Ross, M., Brazier, R.E., 2013. Evaluating ecosystem goods and services after restoration of marginal upland peatlands in SouthWest England. Journal of Applied Ecology 50, 324-334.

Grayson, R., Holden, J., Rose, R., 2010. Long-term change in storm hydrographs in response to peatland vegetation change. Journal of Hydrology 389, 336-343.

Green, S., Boardman, C., Baird, A., Gauci, V., 2011. Investigation of peatland restoration (grip blocking) techniques to achieve best outcomes for methane and greenhouse gas emissions/balance. Controlled Environment (Mesocosm) Experiment. Final report to DEFRA. Project code SP1202. DEFRA.

Holden, J., 2005a. Controls of soil pipe frequency in upland blanket peat. J. Geophys. Res. 110, F01002.

Holden, J., 2005b. Peatland hydrology and carbon release: why small-scale process matters. Philosophical Transactions of the Royal Society a-Mathematical Physical and Engineering Sciences 363, 2891-2913.

Holden, J., 2009. Topographic controls upon soil macropore flow. Earth Surface Processes and Landforms 34, 345-351.

Holden, J., Burt, T.P., 2002. Piping and pipeflow in a deep peat catchment. Catena 48, 163-199.

Holden, J., Burt, T.P., 2003. Runoff production in blanket peat covered catchments. Water Resources Research 39. 
Holden, J., Chapman, P.J., Labadz, J.C., 2004. Artificial drainage of peatlands: hydrological and hydrochemical process and wetland restoration. Progress in Physical Geography 28, 95-123.

Holden, J., Chapman, P.J., Palmer, S.M., Kay, P., Grayson, R., 2012a. The impacts of prescribed moorland burning on water colour and dissolved organic carbon: A critical synthesis. Journal of Environmental Management 101, 92-103.

Holden, J., Evans, M.G., Burt, T.P., Horton, M., 2006. Impact of land drainage on peatland hydrology. Journal of Environmental Quality 35, 1764-1778.

Holden, J., Gascoign, M., Bosanko, N.R., 2007a. Erosion and natural revegetation associated with surface land drains in upland peatlands. Earth Surface Processes and Landforms 32, 1547-1557.

Holden, J., Kirkby, M.J., Lane, S.N., Milledge, D.G., Brookes, C.J., Holden, V., McDonald, A.T., 2008a. Overland flow velocity and roughness properties in peatlands. Water Resources Research 44.

Holden, J., Shotbolt, L., Bonn, A., Burt, T.P., Chapman, P.J., Dougill, A.J., Fraser, E.D.G., Hubacek, K., Irvine, B., Kirkby, M.J., Reed, M.S., Prell, C., Stagl, S., Stringer, L.C., Turner, A., Worrall, F., 2007b. Environmental change in moorland landscapes. Earth-Sci. Rev. 82, 75-100.

Holden, J., Smart, R.P., Dinsmore, K.J., Baird, A.J., Billett, M.F., Chapman, P.J., 2012b. Natural pipes in blanket peatlands: major point sources for the release of carbon to the aquatic system. Global Change Biology 18, 3568-3580.

Holden, J., Walker, J., Evans, M.G., Worrall, F., Bonn, A., 2008b. A compendium of peat restoration and management projects. Defra report SP0556.

Holden, J., Wallage, Z.E., Lane, S.N., McDonald, A.T., 2011. Water table dynamics in undisturbed, drained and restored blanket peat. Journal of Hydrology 402, 103-114.

IUCN, 2013. Peatland Code. 〈http://www.iucn-uk-peatlandprogramme.org/peatland-code/about> . Accessed 01/11/2013.

JNCC, 2008. Second UK report on implimentation of the Habitats directive. Available from <http://jncc.defra.gov.uk/page-4060>. Accessed 10/03/2013.

Jones, J.A.A., 1981. The nature of soil piping: a review of research. Geo Books, Norwich. Joosten, H., 2012. Importance of peatlands for climate change mitigation and adaption, IUCN Peatlands and Climate Change Conference, Bangor University, Wales. .

Labadz, J.C., Burt, T.P., Potter, A.W.R., 1991. Sediment yield and delivery in the blanket peat moorlands of the Southern Pennines. Earth Surface Processes and Landforms 16, 255-271.

Lane, S.N., Milledge, D.G., 2012. Impacts of upland open drains upon runoff generation: a numerical assessment of catchment-scale impacts. Hydrological Processes. 
Lindsay, R.A., 2010. Peatbogs and Carbon: A Critical Synthesis to inform policy development in oceanic peat bog conservation and restoration in the context of climate change. Royal Society for the Protection of Birds, Edinburgh.

Lindsay, R.A., Charman, D.J., Everingham, F., O'Reilly, R.M., Palmer, M., Rowell, T.A., Stroud, D.A., 1988. The flow country: the peatlands of Caithness and Sutherland. Nature Concervancy Council, Peterborough.

Mercer, I., 2009. Dartmoor. Collins, London.

Moors for the Future Partnership., 2012a. Phase 4 - Lime, Seed and Fertiliser. Available from <http://www.moorsforthefuture.org.uk/phase-4-lime-seed-fertiliser>. Accessed 08/04/2013.

Moors for the Future Partnership., 2012b. Phase 5 - Increasing diversity. Available from <http://www.moorsforthefuture.org.uk/phase-5-increasing-diversity>. Accessed on 08/04/2013.

Moors for the Future Partnership., 2012c. Sphagnum Project.

$<$ http://www.moorsforthefuture.org.uk/sphagnum-project>. Accessed on 08/04/2013.

Moors for the Future Partnership., 2012d. Stabalising bare peat. Available from

$<$ http://www.moorsforthefuture.org.uk/phase-3-stabilising-bare-peat >. Accessed 05/04/2013.

Phillips, J., Tallis, J.H., Yalden, D.W., 1981. Peak District moorland erosion study: Phase 1 Peak Park Joint Planning Board, Bakewell.

Price, J., Rochefort, L., Quinty, F., 1998. Energy and moisture considerations on cutover peatlands: surface microtopography, mulch cover and Sphagnum regeneration. Ecological Engineering 10, 293 312.

Price, J.S., 1992. Blanket bog in Newfoundland. Part 2. Hydrological processes. Journal of Hydrology $135,103-119$.

Ramchunder, S.J., Brown, L.E., Holden, J., 2009. Environmental effects of drainage, drain-blocking and prescribed vegetation burning in UK upland peatlands. Progress in Physical Geography 33, 49-79.

Ramchunder, S.J., Brown, L.E., Holden, J., 2012. Catchment-scale peatland restoration benefits stream ecosystem biodiversity. Journal of Applied Ecology 49, 182-191.

Ramchunder, S.J., Brown, L.E., Holden, J., 2013. Rotational vegetation burning effects on peatland stream ecosystems. Journal of Applied Ecology.

Reed, M.S., Hubacek, K., Bonn, A., Burt, T.P., Holden, J., Stringer, L.C., Beharry-Borg, N., Buckmaster, S., Chapman, D., Chapman, P.J., Clay, G.D., Cornell, S.J., Dougill, A.J., Evely, A.C., Fraser, E.D.G., Jin, N., Irvine, B.J., Kirkby, M.J., Kunin, W.E., Prell, C., Quinn, C.H., Slee, B., Stagl, S., Termansen, M., Thorp, S., Worrall, F., 2013. Anticipating and Managing Future Trade-offs and Complementarities between Ecosystem Services. Ecology and Society 18. 
Renou-Wilson, F., Bolger, T., Bullock, C., Convery, F., Curry, J., Ward, S.M., Wilson, D., Muller, C., 2011. BOGLAND: Sustainable Management of Peatlands in Ireland. Irish Environmental Protection Agency. Co. Wexford.

Rochefort, L., Quinty, F., Campeau, S., Johnson, K., Malterer, T., 2003. North American approach to the restoration of Sphagnum dominated peatlands. Wetlands Ecology and Management 11, 3-20.

Rothwell, J.J., Evans, M.G., Allott, T.E.H., 2007. Lead contamination of fluvial sediments in an eroding blanket peat catchment. Applied Geochemistry 22, 446-459.

Rothwell, J.J., Robinson, S.G., Evans, M.G., Yang, J., Allott, T.E.H., 2005. Heavy metal release by peat erosion in the Peak District, southern Pennines, UK. Hydrological Processes 19, 2973-2989.

Roulet, N.T., Lafleur, P.M., Richard, P.J.H., Moore, T.R., Humphreys, E.R., Bubier, J., 2007. Contemporary carbon balance and late Holocene carbon accumulation in a northern peatland. Global Change Biology 13, 397-411.

Rowson, J.G., Gibson, H.S., Worrall, F., Ostle, N., Burt, T.P., Adamson, J.K., 2010. The complete carbon budget of a drained peat catchment. Soil Use and Management 26, 261-273.

Simmons, I.G., 2003. The Moorlands of England and Wales: An Environmental History 8, 000 BCAD 2, 000. Edinburgh University Press, Edinburgh.

Smart, S.M., Henrys, P.A., Scott, W.A., Hall, J.R., Evans, C.D., Crowe, A., Rowe, E.C., Dragosits, U., Page, T., Whyatt, J.D., Sowerby, A., Clark, J.M., 2010. Impacts of pollution and climate change on ombrotrophic Sphagnum species in the UK: analysis of uncertainties in two empirical niche models. Climate Research 45, 163-U507.

Smith, A.G., Cloutman, E.W., 1988. Reconstruction of holocene vegetation history in three dimensions at Waun-Fignen-Felen, an upland site in south Wales. Philosophical Transactions of the Royal Society of London Series B-Biological Sciences 322, 159.

Strack, M., Waller, M.F., Waddington, J.M., 2006. Sedge Succession and Peatland Methane Dynamics: A Potential Feedback to Climate Change. Ecosystems 9, 278-287.

Tallis, J.H., 1987. Fire and flood at Holme Moss: Erosion Processes in an Upland Blanket Mire. Journal of Ecology 75, 1099 - 1129.

Tallis, J.H., 1997. The southern Pennine experience: an overview of blanket mire degradation, in: Tallis, J.H., Meade, R., Hulme, P.D. (Eds.), Blanket mire degradation: causes, concequences and challenges. Macaulay Land Use Research Institute, Aberdeen, pp. 1 - 9.

Tipping, E., Woof, C., Rigg, E., Harrison, A.F., Ineson, P., Taylor, K., Benham, D., Poskitt, J., Rowland, A.P., Bol, R., Harkness, D.D., 1999. Climatic influences on the leaching of dissolved 
organic matter from upland UK moorland soils, investigated by a field manipulation experiment. Environment International 25, 83-95.

Waddington, J.M., Day, S.M., 2007. Methane emissions from a peatland following restoration. Journal of Geophysical Research: Biogeosciences 112, G03018.

Waddington, J.M., Lucchese, M.C., Duval, T.P., 2011. Sphagnum moss moisture retention following the re-vegetation of degraded peatlands. Ecohydrology 4, 359-366.

Waddington, J.M., Roulet, N.T., 1996. Atmosphere-wetland carbon exchanges: Scale dependency of $\mathrm{CO} 2$ and $\mathrm{CH} 4$ exchange on the developmental topography of a peatland. Global Biogeochemical Cycles 10, 233-245.

Wallage, Z.E., Holden, J., 2011. Near-surface macropore flow and saturated hydraulic conductivity in drained and restored blanket peatlands. Soil Use and Management 27, 247-254.

Wallage, Z.E., Holden, J., McDonald, A.T., 2006. Drain blocking: An effective treatment for reducing dissolved organic carbon loss and water discolouration in a drained peatland. Science of the Total Environment 367, 811-821.

Ward, S.E., Bardgett, R.D., McNamara, N.P., Adamson, J.K., Ostle, N.J., 2007. Long-term consequences of grazing and burning on northern peatland carbon dynamics. Ecosystems 10, 10691083.

Wellock, M.L., Reidy, B., Laperle, C.M., Bolger, T., Kiely, G., 2011. Soil organic carbon stocks of afforested peatlands in Ireland. Forestry 84, 441-451.

Wilson, L., Wilson, J., Holden, J., Johnstone, I., Armstrong, A., Morris, M., 2010. Recovery of water tables in Welsh blanket bog after drain blocking: Discharge rates, time scales and the influence of local conditions. Journal of Hydrology 391, 377-386.

Wilson, L., Wilson, J., Holden, J., Johnstone, I., Armstrong, A., Morris, M., 2011a. Ditch blocking, water chemistry and organic carbon flux: Evidence that blanket bog restoration reduces erosion and fluvial carbon loss. Science of the Total Environment 409, 2010-2018.

Wilson, L., Wilson, J., Holden, J., Johnstone, I., Armstrong, A., Morris, M., 2011b. The impact of drain blocking on an upland blanket bog during storm and drought events, and the importance of sampling-scale. Journal of Hydrology 404, 198-208.

Worrall, F., Armstrong, A., Holden, J., 2007. Short-term impact of peat drain-blocking on water colour, dissolved organic carbon concentration, and water table depth. Journal of Hydrology 337, 315325.

Worrall, F., Evans, M.G., Bonn, A., Reed, M.S., Chapman, D., Holden, J., 2009. Can carbon offsetting pay for upland ecological restoration? Science of the Total Environment 408, 26-36. 
Worrall, F., Rowson, J.G., Evans, M.G., Pawson, R., Daniels, S., Bonn, A., 2011. Carbon fluxes from eroding peatlands - the carbon benefit of revegetation following wildfire. Earth Surface Processes and Landforms 36, 1487-1498.

Yallop, A.R., Thacker, J.I., Thomas, G., Stephens, M., Clutterbuck, B., Brewer, T., Sannier, C.A.D., 2006. The extent and intensity of management burning in the English uplands. Journal of Applied Ecology 43, 1138-1148.

Yorkshire Peat Partnership, 2010. Technical guidance note 4: Specification for heather cutting and baling. Available from <http://www.yppartnership.org.uk/restoration/technical-guidance-notes/>. Accessed 08/04/2011.

Yorkshire Peat Partnership., 2011. Technical guidance note 3: specification for the restoration of bare/eroding peat. Available from <http://www.yppartnership.org.uk/>. Accessed on 08/04/2013. 


\section{Tables}

\section{List of tables}

Table 1: The impacts of restoration practices on blanket peatlands, $\uparrow$ indicates an increase, $\downarrow$ a decrease, $*$ denotes where an understanding of response has been derived indirectly as direct empirical data are limited. Light grey boxes indicate a positive impact, dark grey a negative impact a question mark/white box represents an unknown impact. The table outlines an indication of general trends, while variability in response will occur both within and between blanket peatlands as a result of spatial and temporal variability.

Table 2 Studies considering DOC or water colour response to ditch blocking in blanket peatlands

\section{Tables}

Table 1

\begin{tabular}{lccccccc}
\hline & $\begin{array}{l}\text { Stream } \\
\text { peak } \\
\text { flow }\end{array}$ & $\begin{array}{c}\text { Water } \\
\text { table }\end{array}$ & DOC & $\begin{array}{c}\text { POC / } \\
\text { Sediment }\end{array}$ & $\begin{array}{c}\text { Aquatic } \\
\text { ecology } \\
\text { diversity / } \\
\text { abundance }\end{array}$ & $\begin{array}{c}\text { Terrestrial } \\
\text { ecology } \\
\text { diversity / } \\
\text { abundance }\end{array}$ & $\begin{array}{c}\text { Climate } \\
\text { forcing }\end{array}$ \\
\hline $\begin{array}{l}\text { Grip } \\
\text { blocking }\end{array}$ & $\downarrow$ & $\uparrow$ & $\downarrow$ & $\downarrow$ & $\uparrow$ & $\uparrow *$ & $\downarrow *$ \\
\hline $\begin{array}{l}\text { Gully } \\
\text { blocking }\end{array}$ & $?$ & $\uparrow *$ & $\uparrow *$ & $\downarrow$ & $\uparrow *$ & $?$ & $?$ \\
\hline $\begin{array}{l}\text { Seed, lime, } \\
\text { fertiliser }\end{array}$ & $\downarrow *$ & $?$ & $?$ & $\downarrow *$ & $?$ & $?$ & $?$ \\
\hline $\begin{array}{l}\text { Bare peat } \\
\text { stabilisation }\end{array}$ & $\downarrow *$ & $?$ & $?$ & $\downarrow *$ & $\uparrow *$ & $?$ & $\downarrow$ \\
\hline
\end{tabular}


Table two

\begin{tabular}{|c|c|c|c|c|c|}
\hline Study & Study type & Area sampled & $\begin{array}{l}\text { Sampled } \\
\text { from }\end{array}$ & $\begin{array}{l}\text { Time since } \\
\text { block }\end{array}$ & Finding \\
\hline $\begin{array}{l}\text { Wallage et al. } \\
\text { (2006) }\end{array}$ & Comparative & $\begin{array}{l}\text { Small number } \\
\text { of drainage } \\
\text { channels }\end{array}$ & $\begin{array}{l}\text { Peat pore } \\
\text { waters }\end{array}$ & $\sim 5$ years & $\begin{array}{l}\text { DOC } \\
\text { concentration } \\
\text { decrease }\end{array}$ \\
\hline $\begin{array}{l}\text { Worrall et al. } \\
(2007)\end{array}$ & $\begin{array}{l}\text { Before / After } \\
\text { Comparative }\end{array}$ & Catchment & $\begin{array}{l}\text { In stream and } \\
\text { in drain }\end{array}$ & $\begin{array}{l}1 \text { month } \\
\text { before / } 8 \\
\text { months after }\end{array}$ & $\begin{array}{l}\text { Water colour } \\
\text { increase }\end{array}$ \\
\hline $\begin{array}{l}\text { UK national } \\
\text { survey } \\
\text { Armstrong et } \\
\text { al. (2010) }\end{array}$ & Comparative & $\begin{array}{l}\text { National } \\
\text { survey }\end{array}$ & In drain & $\begin{array}{l}\text { Varied }(0.5 \\
-18 \text { years })\end{array}$ & $\begin{array}{l}\text { DOC } \\
\text { concentration } \\
\text { and water colour } \\
\text { decrease }\end{array}$ \\
\hline $\begin{array}{l}\text { Intensive } \\
\text { study } \\
\text { Armstrong et } \\
\text { al. (2010) }\end{array}$ & Comparative & $\begin{array}{l}\text { Small number } \\
\text { of drainage } \\
\text { channels and } \\
\text { catchment grab } \\
\text { samples }\end{array}$ & In drain & $\sim 7$ years & $\begin{array}{l}\text { No response in } \\
\text { total export or } \\
\text { concentration }\end{array}$ \\
\hline $\begin{array}{l}\text { Wilson et al. } \\
\text { (2011a) }\end{array}$ & $\begin{array}{l}\text { Before / After } \\
\text { Comparative }\end{array}$ & $\begin{array}{l}\text { Drains and } \\
\text { streams in } \\
\text { three } \\
\text { catchments }\end{array}$ & $\begin{array}{l}\text { In stream and } \\
\text { in drain }\end{array}$ & 3 years after & $\begin{array}{l}\text { DOC export and } \\
\text { concentration } \\
\text { decline }\end{array}$ \\
\hline $\begin{array}{l}\text { Turner et al. } \\
\text { (2013) }\end{array}$ & $\begin{array}{l}\text { Before / After } \\
\text { With control }\end{array}$ & $\begin{array}{l}\text { Small } \\
\text { catchments }\end{array}$ & In drain & $\begin{array}{l}1 \text { year } \\
\text { before / } 1 \\
\text { year after }\end{array}$ & $\begin{array}{l}\text { DOC export and } \\
\text { concentration (at } \\
\text { first order) } \\
\text { decline }\end{array}$ \\
\hline $\begin{array}{l}\text { Gibson et al. } \\
(2009)\end{array}$ & Comparative & $\begin{array}{l}\text { Small number } \\
\text { of drainage } \\
\text { channels }\end{array}$ & In drain & $1-9$ years & $\begin{array}{l}\text { Decrease in } \\
\text { DOC export, no } \\
\text { change in } \\
\text { concentration }\end{array}$ \\
\hline
\end{tabular}




\section{List of figures}

Figure 1: An example of degradation features occurring within a small area of blanket peatland in North Pennines, UK: a. artificial drainage channels, b. gully network and c. 'hagg field' with dendritic anastomising gullies.

Figure 2: Blocking techniques used for artificial drainage channels: a. peat dam keyed in with bare peat covered; b. wooden dam; c. plastic piling dam; and d. heather bale dam.

Figure 3: Recently created gully blocks a. using plastic piling b. using stone dams. Note the variability in gully condition between the pictures.

Figure 4: Stabilisation techniques: a. heather brash on gentle slopes; b. geo-jute on steep hagged areas; c. heather bales restricting flow in incising channels; d. coir logs containing overland flow

\section{Figure 1}

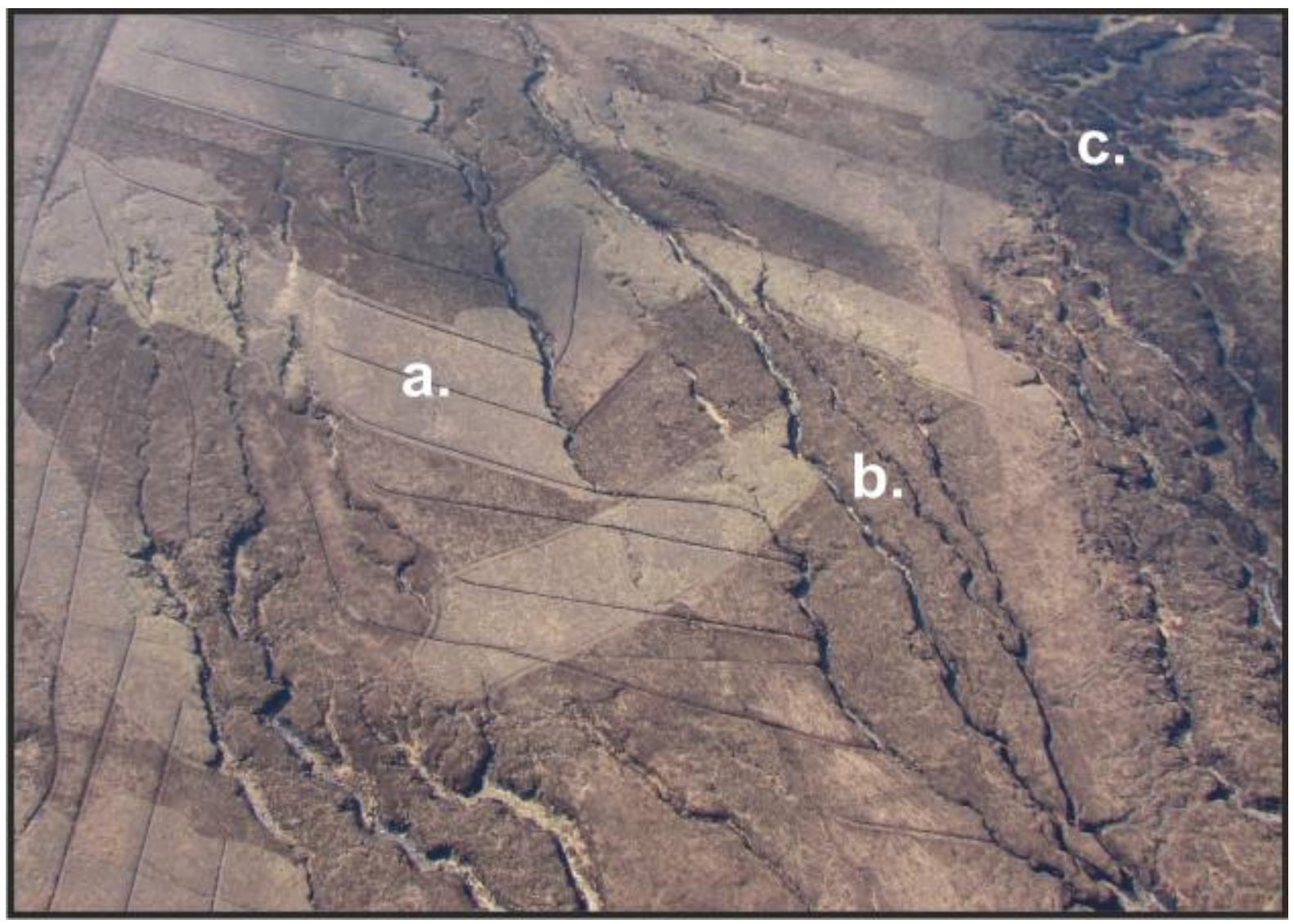


Figure 2
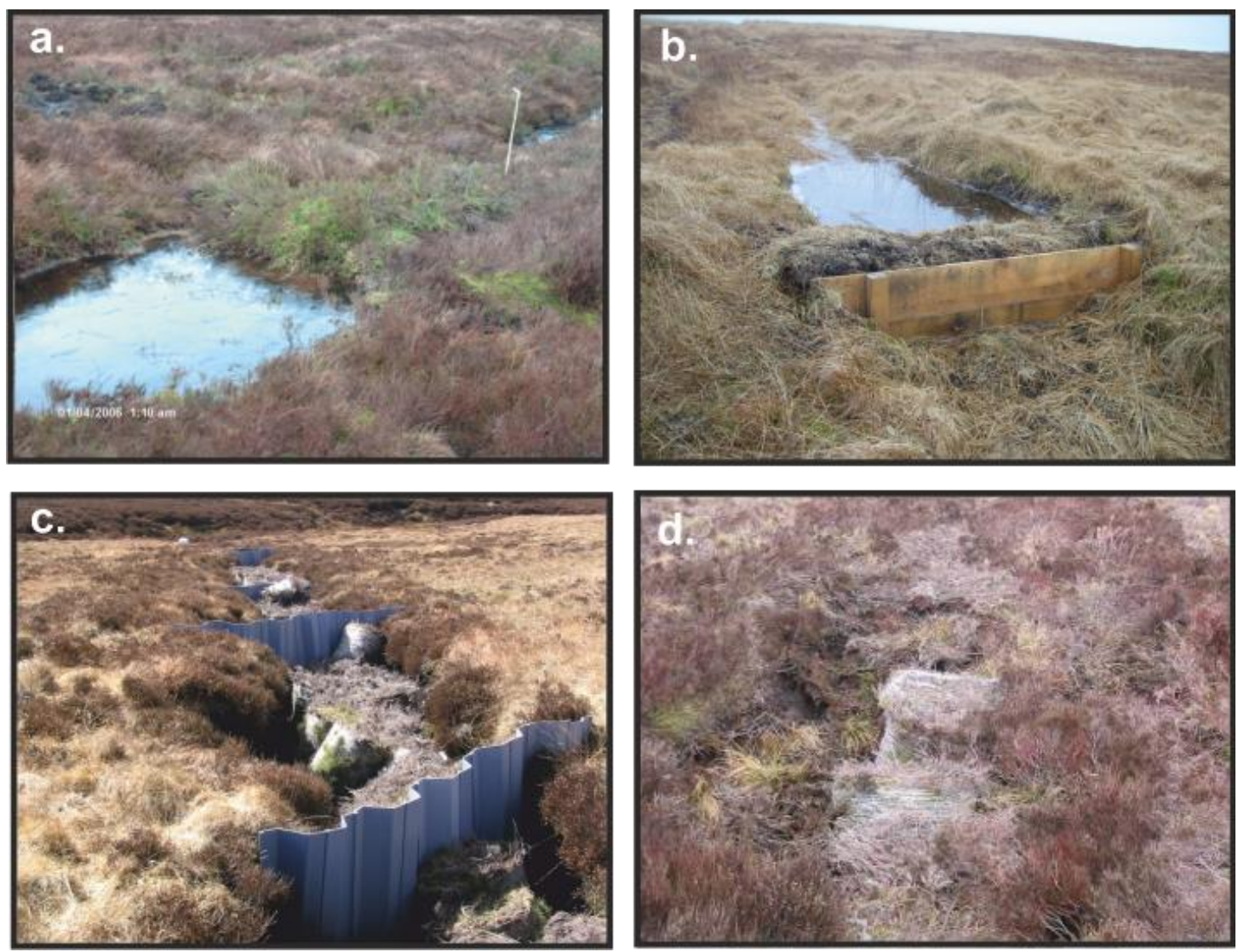

Figure 3
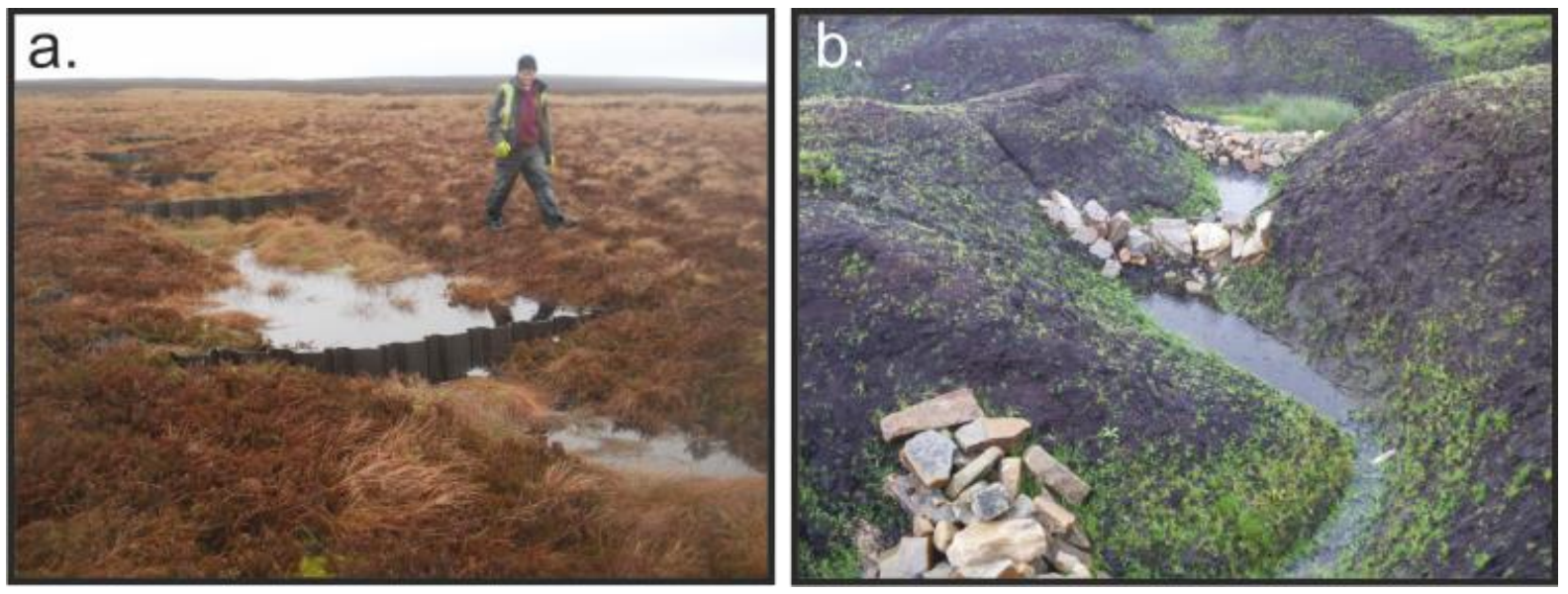
Figure 4
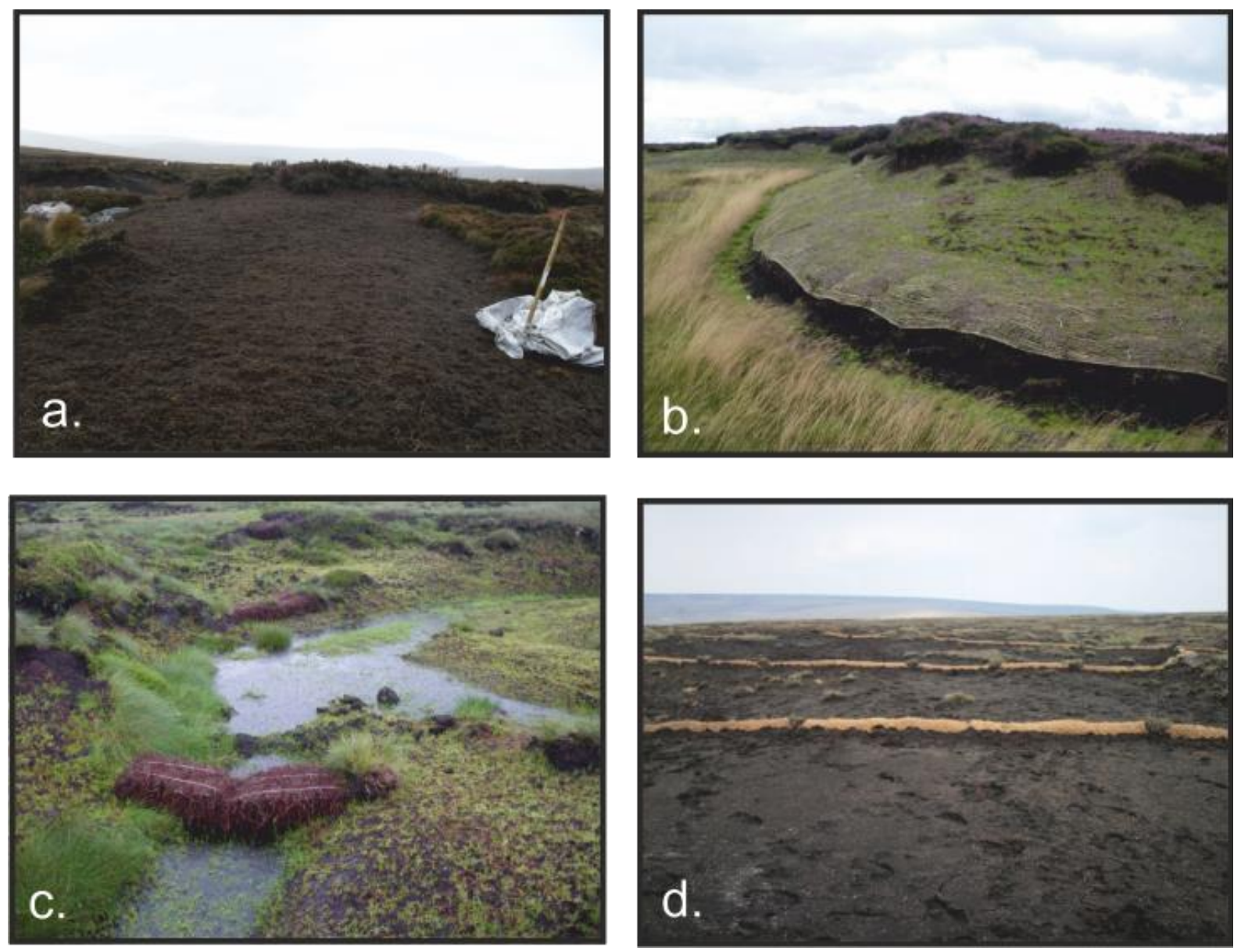